\title{
Assessment of comparative effects of sodium chloride stress on various growth parameters in different verities of rice (Oryza sativa L.)
}

\author{
Sher Wali, Izhar Ahmad*, Faheem Tariq, Arif Ali and Syed Inzimam U1 \\ Haq \\ Department of Botany, Islamia College Peshawar, Khyber Pakhtunkhwa-Pakistan \\ *Corresponding author's email: izhar.ahmad@icp.edu.pk
}

\section{Citation}

Sher Wali, Izhar Ahmad, Faheem Tariq, Arif Ali and Syed Inzimam Ul Haq. Assessment of comparative effects of sodium chloride stress on various growth parameters in different verities of rice (Oryza sativa L.). Pure and Applied Biology. Vol. 6, Issue 2, pp707-717. http://dx.doi.org/10.19045/bspab.2017.60075

\begin{tabular}{llll}
\hline \hline Received: $12 / 04 / 2017$ & Revised: 09/05/2017 & Accepted: 26/05/2017 & Online First: 02/06/2017 \\
\hline \hline
\end{tabular}

\section{Abstract}

Rice (Oryza sativa L.) belongs to family Poaceae. It is a cereal grain cultivated throughout the world. Rice is one of the largest crop products of Pakistan. In the present study of two varieties of Rice (Oryza sativa L.), Swat Sella and Punjab Basmati varieties were studied in vitro for the assessment of germination and different growth parameters. These varieties were subjected in hydroponic culture to $100 \mathrm{mM}, 200 \mathrm{mM}$, and $300 \mathrm{mM}$ of $\mathrm{NaCl}$ and compared with control. The increase in concentration of $\mathrm{NaCl}$ adversely affected the seedling germination and growth parameters. The results showed that Swat Sella rice variety showed greater average number of seeds germination, radicle length and plumule length in $100 \mathrm{mM}, 200 \mathrm{mM}$, and $300 \mathrm{mM}$ of $\mathrm{NaCl}$ compared to Punjab variety. However, in controlled medium, it was observed that Punjab variety showed higher fresh weight of seedlings, plumule length, root length of plants, shoot length of plants and dry weight of plants in comparison to Swat variety. It can be concluded that the Swat Sella rice variety is better adopted and can grow better in salinity compared to Punjab variety that grows best in non-saline conditions.

Keywords: Rice (Oryza sativa L.); Swat sella; Punjab basmati; $\mathrm{NaCl}$; Hydroponic culture

\section{Introduction}

Rice (Oryza sativa L.) belongs to family Poaceae which is considered as cereal grain and cultivated throughout the world. Rice plant grows best from the altitude above 25,000 meter above sea level or even at higher altitude. The rice plant is one the largest crop products of Pakistan. It come at second position after the wheat as a staple food and form kharif crop of Pakistan. Rice is monocotyledonous plant and one of the important export items of Pakistan. Rice holds $2.7 \%$ of agriculture and $0.6 \%$ of GDP value [1]. Rice is the third mostly cultivated crop after wheat and maize it is mostly cultivated in the mountain and plain areas of Khyber Pakhtunkhwa (KPK). During 20082009, 7349 hectares of land was cultivated with rice [2]. 
The stress is a physiological response to different situations. During the normal condition in which plant grow the metabolism process of the plant help to develop responses to changing environment, that disturb regular, daily and seasonal cycles [3]. Stress on plant is defined as any external biotic (animals, microbes etc.) or abiotic (temperature, water, heat, salinity etc.) feature that restrict photosynthetic rate and limit the biomass production [4]. Under change growth conditions, metabolic processes of the plant adjust itself in such away new state of homeostasis is achieved; this is called as acclimation [5]. Plant stress is measure in term of crop yield, growth, plant death or survival. Productivity of the crops is greatly reduced due to abiotic stresses [6]. The plant can face abiotic stresses that include freezing, immoderate temperature, saline or decrease availability of water, decreased amount of essential nutrient in soil, extreme light, and hindrance to root growth due to hardness of soil [7].

FAO [8] reported one of the biggest challenge toward to the agricultural production is to produce $70 \%$ more food crops by 2050 worldwide for extra 2.3 billion people. Salinity is most important stress that ultimately comes in way of increase demand for food crop. More than $20 \%$ of cultivated land is affected by salt stress world widely (about 45 hectares). Adaptive evolution of plants is of two types: halophytes (which can grow in saline condition) and glycophytes (which are not salt tolerant and finally die). The world nearly $7 \%$ total area seriously affected by salinity [9]. Salinity causes reduction in yield and quantity by affecting plant growth and developmental process [10]. In Pakistan, almost $12.9 \%$ of country land is effected badly by salinity as count for 10 million ha area [11].

Like all plants rice also shows variation for salinity tolerance $[12,13]$. Plant growth and development is affected by one of the most important abiotic stresses such as salinity $[14,15]$. Rice plants show tolerance toward salinity during germination whereas, the growth stage such as panicle initiation and pollination stages are quite sensitive toward salinity that directly related to yield [16]. High salinity condition causes necrosis and burning of leaf tips due to injection of $\mathrm{Na}^{+}$ and $\mathrm{Cl}^{-}[17]$.

In Halophytic Grass Aeluropus lagopoides due to high salinity the rate of germination decreases, with warmer temperature germination increase however when effected seeds provided with distilled water and warmer temperature seed recover quickly with optimum response [18]. The water stress or salinity effect the plant in many ways i.e. it reduces their ability to take up water, effect the growth rate and it also bring about metabolic changes govern by salinity stresses [19]. Germination is inhibited by increased salinity however; the stimulus of germination toward light depends on type of perennial grasses [20]. Salinity causes sterility in Oryza sativa L. that eventually lead to yield losses [21].

Two approaches to produce salt tolerant crops are (i) selection of plant with genetic diversity i.e. through direct selection in saline environment, gene mapping and by setting certain marker (ii) introducing the gene of interest to produce transgenic plant or expression of the gene changed up to degree of salt stress tolerance [22]. $\mathrm{Na}^{+}$and $\mathrm{Cl}^{-}$content increased after salt treatment but $\mathrm{K}^{+}$decreases in flag leaves and roots of rice (Oryza sativa L.). Phosphorus applied through root inhibit $\mathrm{Na}^{+}$and $\mathrm{Cl}^{-}$ accumulation while it increases $\mathrm{K}^{+}, \mathrm{P}, \mathrm{Ca}^{2+}$ in leaf and root opposite to effect of salt stress in Oryza sativa L. [23]. In rice and wheat accumulation of $\mathrm{K}^{+}$and biomass production depend on level of $\mathrm{NH}_{4}^{+}$and $\mathrm{K}^{+}$ whereas, there interaction changes with the soil type [24]. N, P, K, Ca, and Mg nutrient 
present in rice and wheat can be increased by applying chemicals of these nutrients in soil or providing them with plant compost [25]. Under saline condition tolerant genotype show greater leaf area, osmotic potential, glycine-betaine in wheat, chlorophyll and sugar content [26]. Large amount of salinity stress affects rice plant fresh shoot weight, seedling fresh weight and specific shoot length in comparison to that shoot length, root length, seedling length and there dry and fresh weight are less effected [27]. The rice plant should be irrigated with saline water in final growth stages [28]. Oryza sativa L. seed breaks dormancy when it is provided with combination of conditions i.e. seed hull removal, heat or chemical treatments then germinated it in optimum temperature [29]. In rice plant growth and yield can be increased by applying $\mathrm{Si}$ in suitable concentration at a proper time [30]. Insufficient water for irrigation directly affect morphological, anatomical, physiological and yield of rice plant [31]. Rice plant with salt tolerance genome or genotype could have potential germplasm source in future breeding programs. [32]. Drought effects growth and physiological activities of Oryza sativa L. finally, causes decrease in amount of yield further on increasing water stress result in proline accumulation and malondialdehyde [33].

The aims and objective of study was to examine the various parameters of different verities in Oryza sativa L. under salinity stress; effect of $\mathrm{NaCl}$ on germination, plumula length, radicle root length, shoot length, leaf chlorophyll content, fresh weight of the plant, dry weight of plant.

\section{Materials and methods}

Oryza sativa L. (rice) seeds of two different verities i.e. Punjab Basmati rice and Swat Sella rice verity were selected. All the research work was conducted in Islamia
College university Peshawar laboratory as well as in botanical garden.

The chemicals were obtained from various sources that include companies such as Riedel-de-haen, Analar (England), Merck (Germany), Sigma-Aldrich (USA) and Scharlau (Spain).

The petri dishes were used for germination of rice seeds before they could be used they were sterilized with distilled water later the thermal sterilization in auto clave at a temperature of $100^{\circ} \mathrm{C}$ for approximately 2 hours. Later, seeds were germinated on two folds of moistened filter paper. Petri dish was providing with 3 different solution $100 \mathrm{mM}, 200 \mathrm{mM}$ and $300 \mathrm{mM}$ of $\mathrm{NaCl}$ and one was grown in non-saline water was kept as control. Seeds were kept in an incubator at a temperature of $28^{\circ} \mathrm{C}$ to $30^{\circ} \mathrm{C}$ providing it with $90 \%$ of humidity. After 10 days germinated seedlings parameters such as length of the plumule, length of radicle and percentage of germination were recorded.

Hydroponic culture technique (Figure 7) was used to grow the seedling further on and to examine the root growth and elongation easily. The seedlings which were grown in non-saline condition are the transferred to the rectangular boxes covered with duct tape in such away root remain in darkness. The plants were provided with essential nutrients via hydroponic culture medium. The hydroponic culture medium consisting to two types of solution, micro nutrients and macronutrients are shown in Table 1. Later, the growth medium was provided with saline condition by adding $\mathrm{NaCl}$ to increase the concentration of $\mathrm{Na}^{+}$to about $60 \mathrm{mM}$, for osmotic stress medium was treated with $5 \%$, $10 \%$, and $15 \%$ of PEG (polyethylene glycol4000).

The rice plants were provided with 16 hours of light and almost 8 hours of dark period, the temperature was maintained between $30^{\circ}$ $\mathrm{C}$ at day and $28^{\circ} \mathrm{C}$ at night, with about $65 \%$ relative humidity. The medium was changed 
every 4 days to avoid nutrient deficiency in plants.

Table 1. Growth media for plants (Macronutrients and Micronutrients)

\begin{tabular}{|l|l|c|c|c|}
\hline Nutrients & Sources & $\begin{array}{l}\text { Preparation of } \\
\text { stock sol. (g/l) }\end{array}$ & $\begin{array}{l}\text { Ml of stock sol. } \\
\text { for medium }\end{array}$ & $\begin{array}{l}\text { Conc. of } \\
\text { elements in } \\
\text { medium (Mm) }\end{array}$ \\
\hline Macronutrients & \multicolumn{5}{l|}{} \\
\hline $\mathrm{N}$ & $\mathrm{NH}_{4} \mathrm{NO}_{3}$ & & \\
\hline $\mathrm{P}$ & $\mathrm{NaH}_{2} \mathrm{PO}_{4} .2 \mathrm{H}_{2} \mathrm{O}$ & 91.4 & 1.25 & 2.9 \\
\hline $\mathrm{K}$ & $\mathrm{K}_{2} \mathrm{SO}_{4}$ & 40.3 & 1.25 & 0.3 \\
\hline $\mathrm{Ca}$ & $\mathrm{CaCl}_{2}$ & 71.4 & 1.25 & 1.0 \\
\hline $\mathrm{Mg}$ & $\mathrm{MgSO}_{4} \cdot 7 \mathrm{H}_{2} \mathrm{O}$ & 88.6 & 1.25 & 1.0 \\
\hline Micronutrients & \multicolumn{5}{|l|}{} \\
\hline $\mathrm{Mn}$ & $\mathrm{MnCl}_{4} \mathrm{H}_{2} \mathrm{O}$ & 1.5 & 1.25 & 0.01 \\
\hline $\mathrm{Mo}$ & $\left(\mathrm{NH}_{4}\right)_{6} \cdot \mathrm{Mo}_{7} \mathrm{O}_{24} .4 \mathrm{H}_{2} \mathrm{O}$ & 0.074 & 1.25 & 0.001 \\
\hline $\mathrm{B}$ & $\mathrm{H}_{3} \mathrm{BO}_{3}$ & 0.934 & 1.25 & 0.2 \\
\hline $\mathrm{Zn}$ & $\mathrm{ZnSO}_{4} \cdot 7 \mathrm{H}_{2} \mathrm{O}$ & 0.035 & 1.25 & 0.0002 \\
\hline $\mathrm{Cu}$ & $\mathrm{CUSO}_{4} \cdot 5 \mathrm{H}_{2} \mathrm{O}$ & 0.031 & 1.25 & 0.0002 \\
\hline $\mathrm{Fe}$ & $\mathrm{FeCl}_{3} \cdot 6 \mathrm{H}_{2} \mathrm{O}$ & 7.7 & 1.25 & 0.04 \\
\hline $\mathrm{Silica}$ & $\mathrm{Na}_{2} \mathrm{SiO}_{3}$ & 0.18 & - & - \\
\hline
\end{tabular}

\section{Growth media for plants}

Distilled water is used to prepare stock solutions. In such a way that each of macronutrients were made individually, whereas micronutrients were dissolved separately along with addition of $50 \mathrm{ml}$ of conc. $\mathrm{H}_{2} \mathrm{SO}_{4}$ volume was made up to 1 litre. The micro and macronutrients were added in below proportion. The $\mathrm{PH}$ was then retained between 5.6 to 5.7 using $\mathrm{NaCl} / \mathrm{KCl}$ and $\mathrm{HCl}$ in suitable amount [34].

\section{Results}

The various parameters of rice plants under different $\mathrm{NaCl}$ concentration and comparing it with that of control medium in two verities were recorded.

\section{Comparing average number of Seeds Germinated, Fresh weight, Radicle and Plumule length in control and different $\mathrm{NaCl}$ concentrations}

Average number of seeds germinated in Punjab and swat rice verities in $100 \mathrm{mM}$, $200 \mathrm{mM}$, and $300 \mathrm{mM} \mathrm{NaCl}$ solutions were recorded. It was observed that in Swat Sella rice verity a greater number of seeds were germinated among all $100 \mathrm{Mm}, 200 \mathrm{Mm}$ and $300 \mathrm{mM}$ solution of $\mathrm{NaCl}$. However, Punjab Basmati rice variety show at least 2 seeds less than that are germinated in Swat Sella rice variety in all the 3-different solutions of $\mathrm{NaCl}$. In control medium, it was observed that Punjab Basmati rice varieties were germinated in greater number (Figure 1). However, in control medium it was observed that Punjab showed greater number of seeds germination than that of Swat Sella rice variety (Figure 2).

The average weight of seedlings that were grown in control condition and in $100 \mathrm{mM}$, $200 \mathrm{mM}$ and $300 \mathrm{mM}$ concentration of $\mathrm{NaCl}$ were recorded. The data showed that the average weight of Swat Sella rice variety was greater in all 3 solutions of $\mathrm{NaCl}$ in comparison to that of Punjab Basmati rice variety (Figure 3). While recording a data, it was observed both the parameter; plumule and radicle length of rice is affected due to salinity. The biomass of rice plant above the ground is almost same below the ground. It was seen that in Swat Sella rice variety the 
average plumule length and radicle length is greater than the Punjab Basmati rice variety in $100 \mathrm{mM}, 200 \mathrm{mM}$ and $300 \mathrm{Mm}$ of $\mathrm{NaCl}$. Whereas, in control medium it was observed

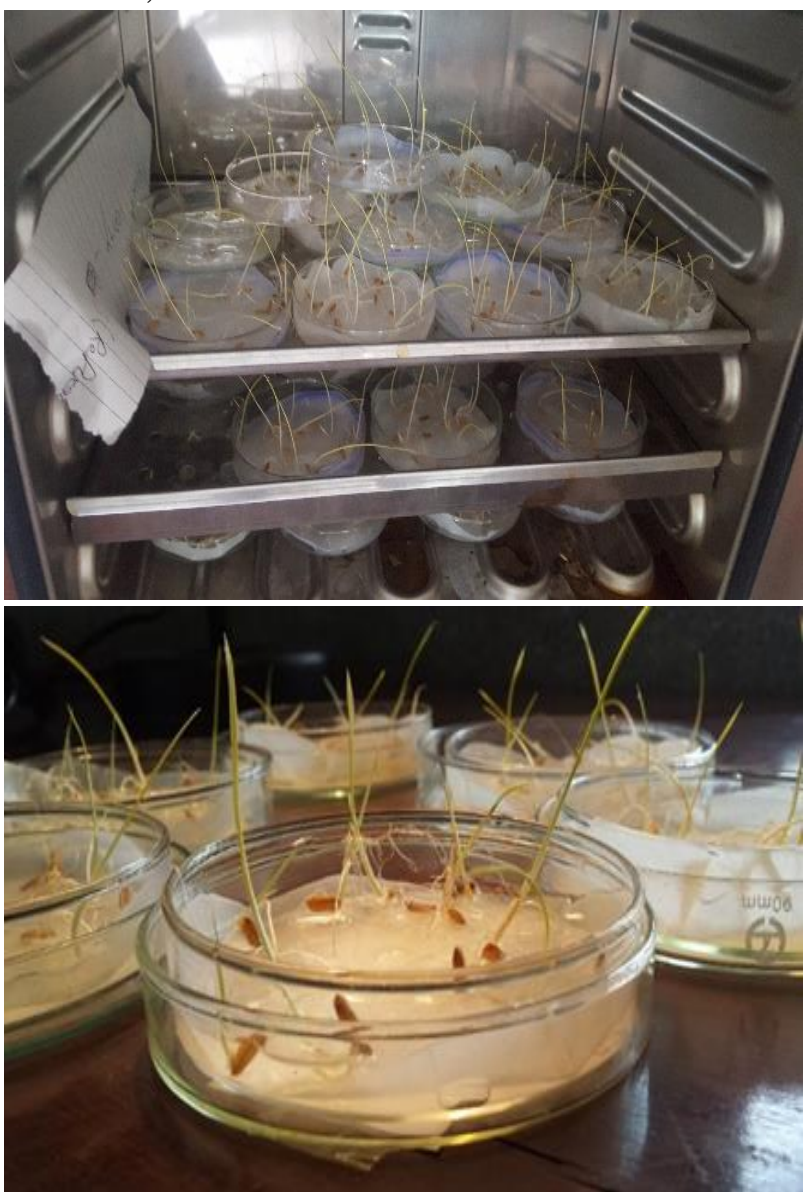

that average length of radicle and plumule in Punjab Basmati rice variety is more than Swat Sella rice variety (Figure 4).

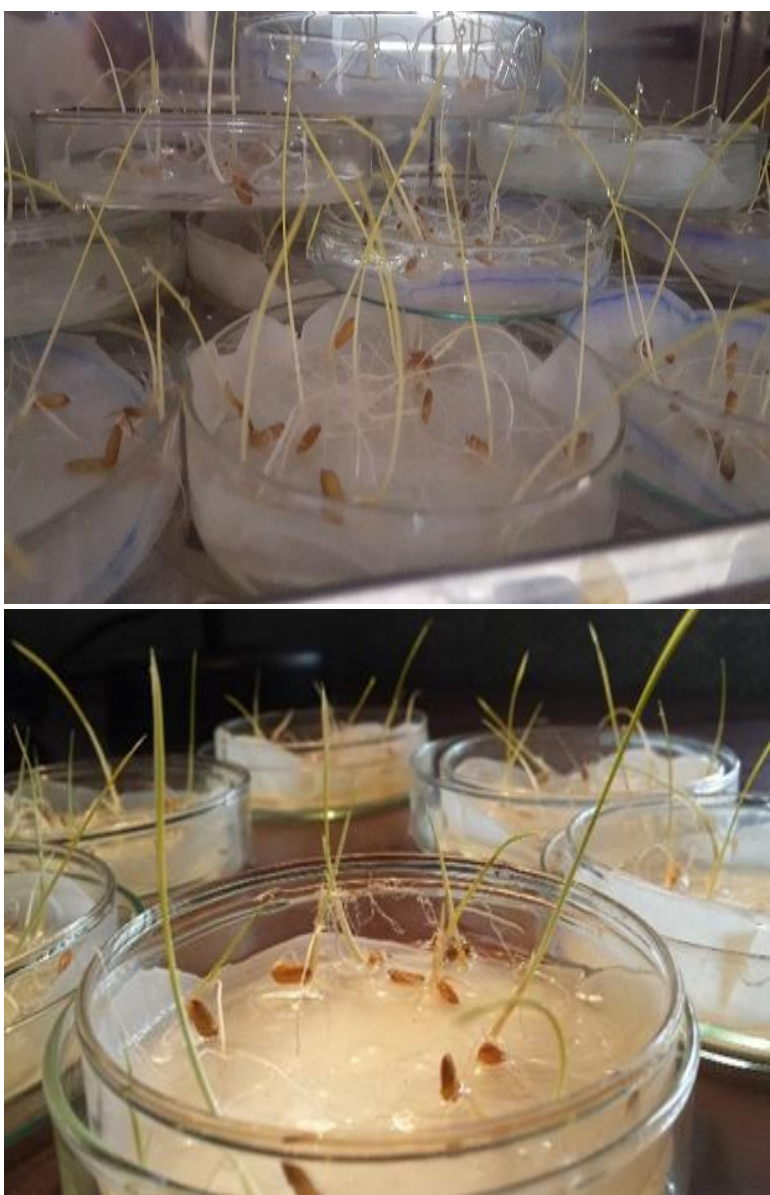

Figure 1. showing rice seeds germination in control and different $\mathrm{NaCl}$ concentrations

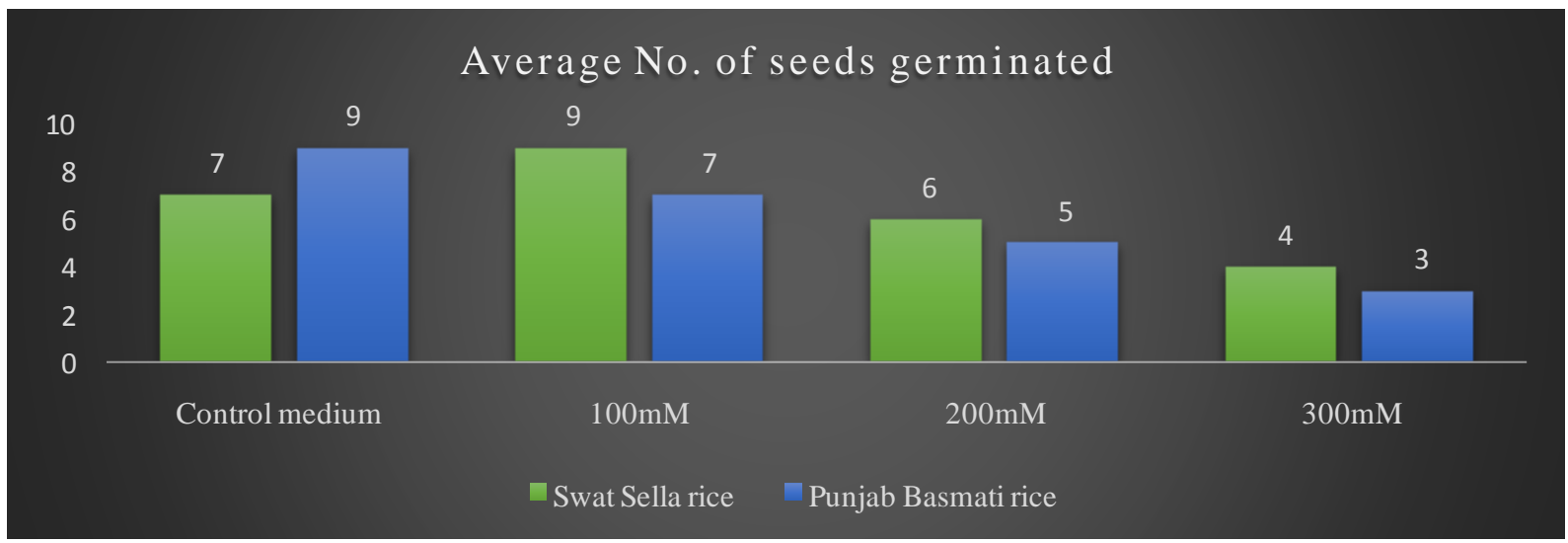

Figure 2. Comparing average No. of seeds germinated in control and different $\mathrm{NaCl}$ concentration. 


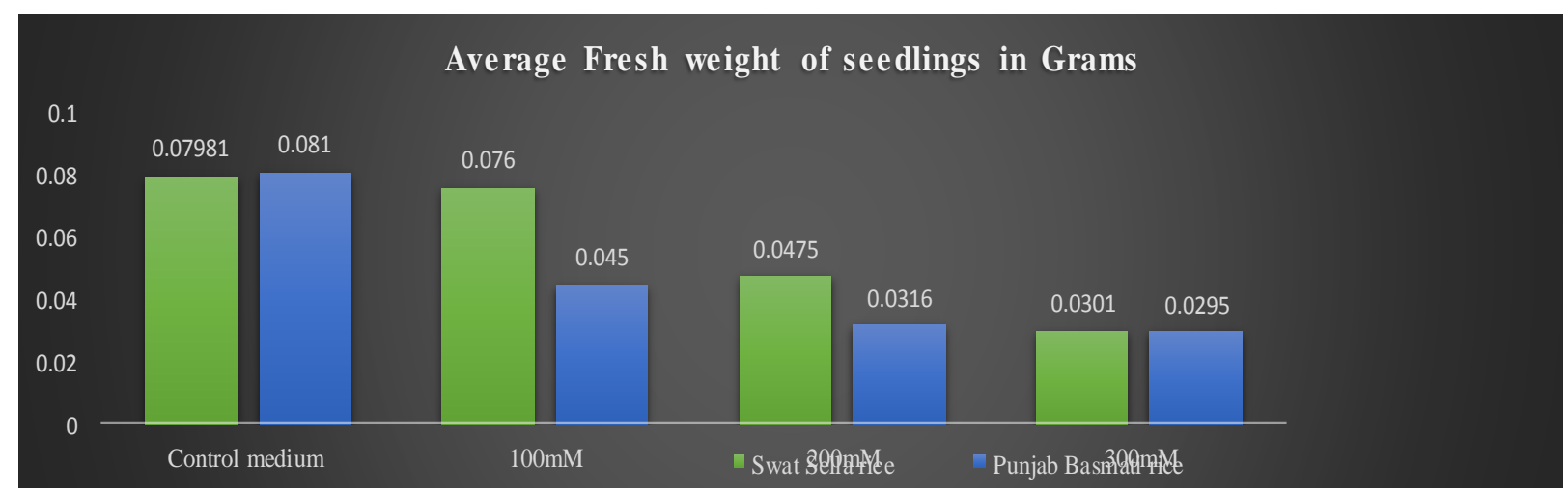

Figure 3. Comparison of fresh weight of seedling in control and different $\mathrm{NaCl}$ concentrations

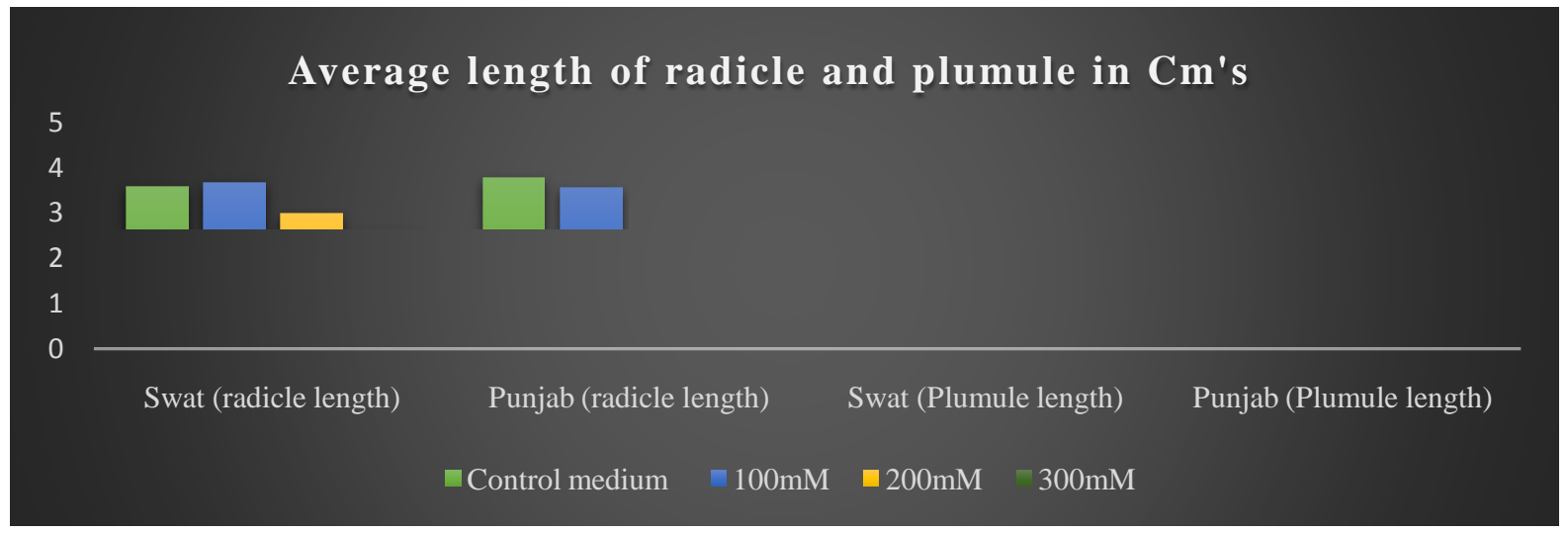

Figure 4. Comparing average length of radicle and plumule in control and different $\mathrm{NaCl}$ concentrations

Fresh weight and dry weight of rice plants in control medium and different concentration of $\mathrm{NaCl}$

The fresh weights of different rice varieties in control medium showed that Swat Sella rice plant have an average weight of 0.7474 grams. Whereas, Punjab Basmati rice plant have an average weight of 0.9488 grams. According to the data, the average weight of fresh biomass in Punjab rice plants are greater as compare to Swat rice verity in control medium. Similarly, when these plants were dried it was seen that Punjab variety contains an average dry weight of 0.2562 grams which was greater than the average dry weight of Swat variety that was 0.1982 grams (Figure 5).

The fresh weight of Swat variety plants was greater than the Punjab variety plants in $100 \mathrm{mM}, 200 \mathrm{mM}$, and $300 \mathrm{mM}$ concentration of $\mathrm{NaCl}$. However, both varieties show decrease in fresh weight of plants, when subjected to increased amount of $\mathrm{NaCl}$. The dry weight of Swat Sella Rice variety was greater as compare to Punjab Basmati rice variety in $100 \mathrm{mM}, 200 \mathrm{mM}$ and $300 \mathrm{mM}$ concentration of $\mathrm{NaCl}$. Dry weight of rice plants decrease with increase in concentration of salinity. 


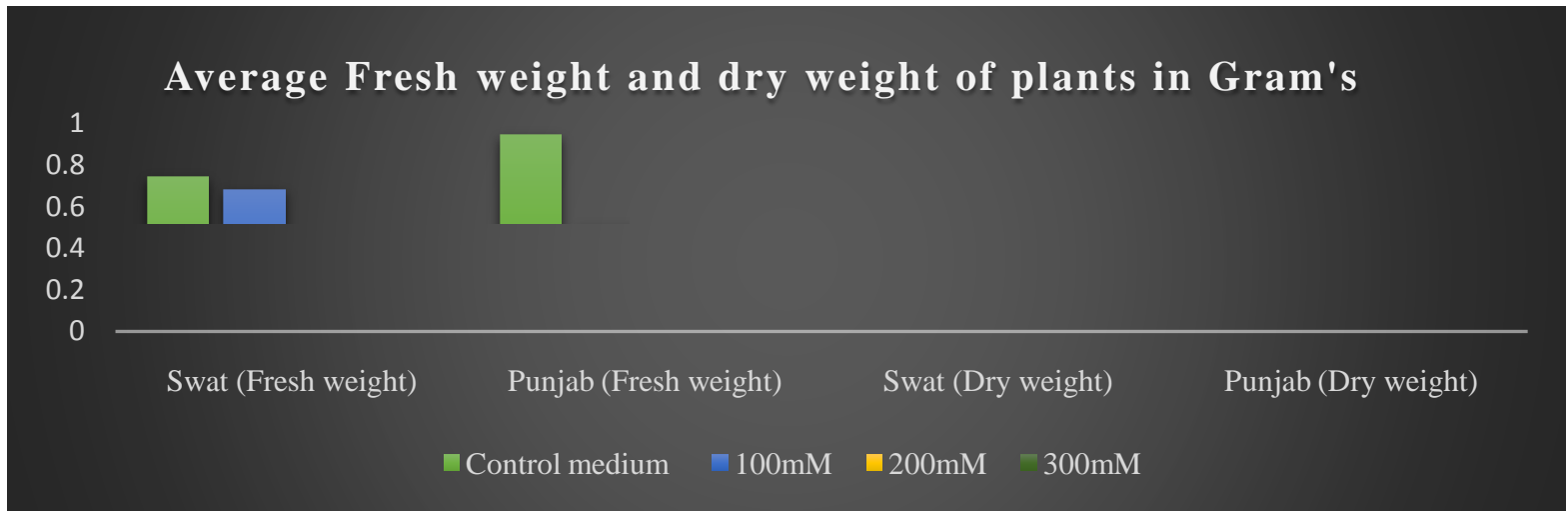

Figure 5. Comparing average fresh weight and dry weight in control and different concentration of $\mathrm{NaCl}$

\section{Comparing average root and shoot length in control and different $\mathrm{NaCl}$ concentration}

The average root lengths of Punjab Basmati rice variety showed a length of about 11.10 $\mathrm{cm}$ which was greater in length from Swat Sella rice variety that was $10.28 \mathrm{~cm}$ in controlled medium. The shoot length of Punjab Basmati rice was also greater in length with $18.09 \mathrm{~cm}$ whereas, in Swat Sella rice variety, an average length was $16.11 \mathrm{~cm}$ in different concentration of $\mathrm{NaCl}$ i.e. $100 \mathrm{mM}, 200 \mathrm{mM}$ and $300 \mathrm{mM}$, Swat rice plants showed a greater average length of both root as well as shoot in comparison to Punjab Basmati rice plants. It was observed that with increase in concentration of $\mathrm{NaCl}$ (Salinity stress) the average length of both root as well shoot of plants decreases (Figure 6).

In the present study, it was noticed that the average number of seeds germination decreases with increase in the amount of $\mathrm{NaCl}$ concentration (Figure 2). This decrease was almost 20\% in Punjab Basmati rice variety, Similarly, Swat Sella rice variety show decrease $100 \mathrm{mM}, 200 \mathrm{mM}$ and300mM. However, the Average number of germinated seeds of swat variety at each $100 \mathrm{mM}, 200 \mathrm{mM}$ and $300 \mathrm{mM}$ concentration was greater than Punjab Basmati rice variety. This result showed that the swat Sella rice variety was more tolerant to salt stress. Whereas, the Punjab Basmati rice variety was more sensitive. This show agreement with those of Kaymakanova [35] who reported that all the plants cultivars show decrease in percentage of germination, seedling growth when treated with $\mathrm{NaCl}$. The decrease in the average number of seed germination is probably because of the greater osmotic potential in the surrounding as compare to the osmotic potential inside the seeds because of which the seeds does not absorb water properly. It was found that under $100 \mathrm{mM}, 200 \mathrm{mM}$ and $300 \mathrm{mM}$ of $\mathrm{NaCl}$ stress condition the average fresh weight of seedling, average radicle length, average plumule length, average shoot length average root length and fresh weight as well as dry weight of seedling decreases with increase in the concentration of $\mathrm{NaCl}$ (salinity) as shown in (Figure 3 and 4). In Swat Sella rice variety, the fresh weight of seedling is greater as compare to Punjab Basmati rice variety. Similarly, average radicle lengths as well as plumula average lengths of seedling of Swat Sella rice variety are greater than Punjab Basmati rice variety. 


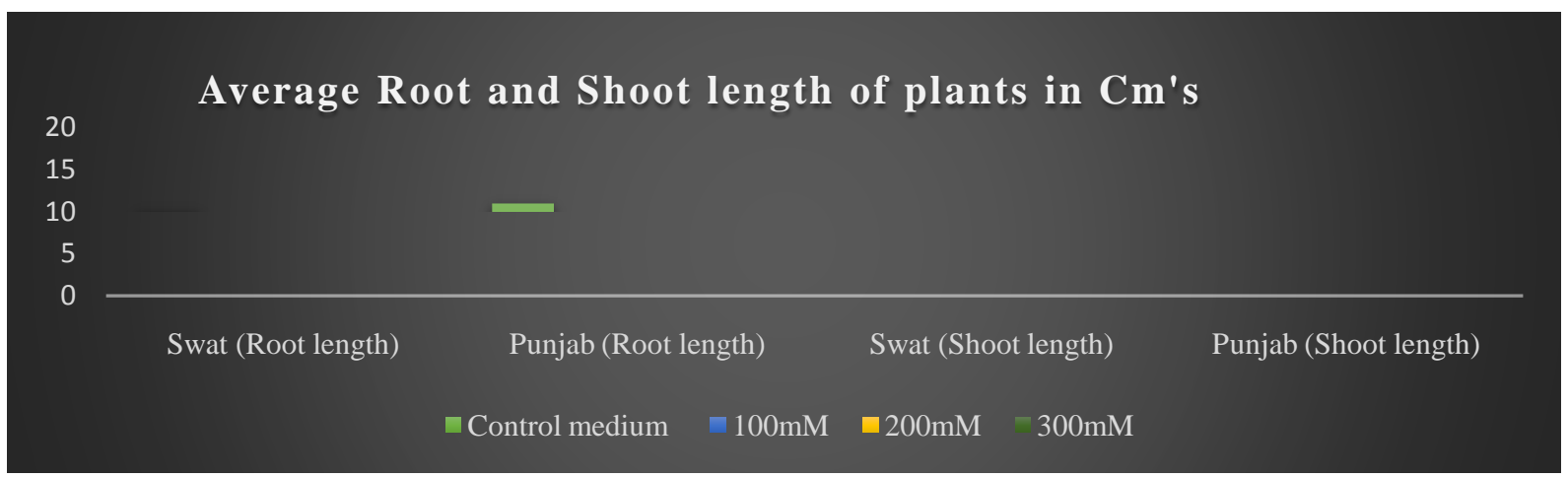

Figure 6. Comparing average root and shoot length of different rice varieties in control and different concentration of $\mathrm{NaCl}$

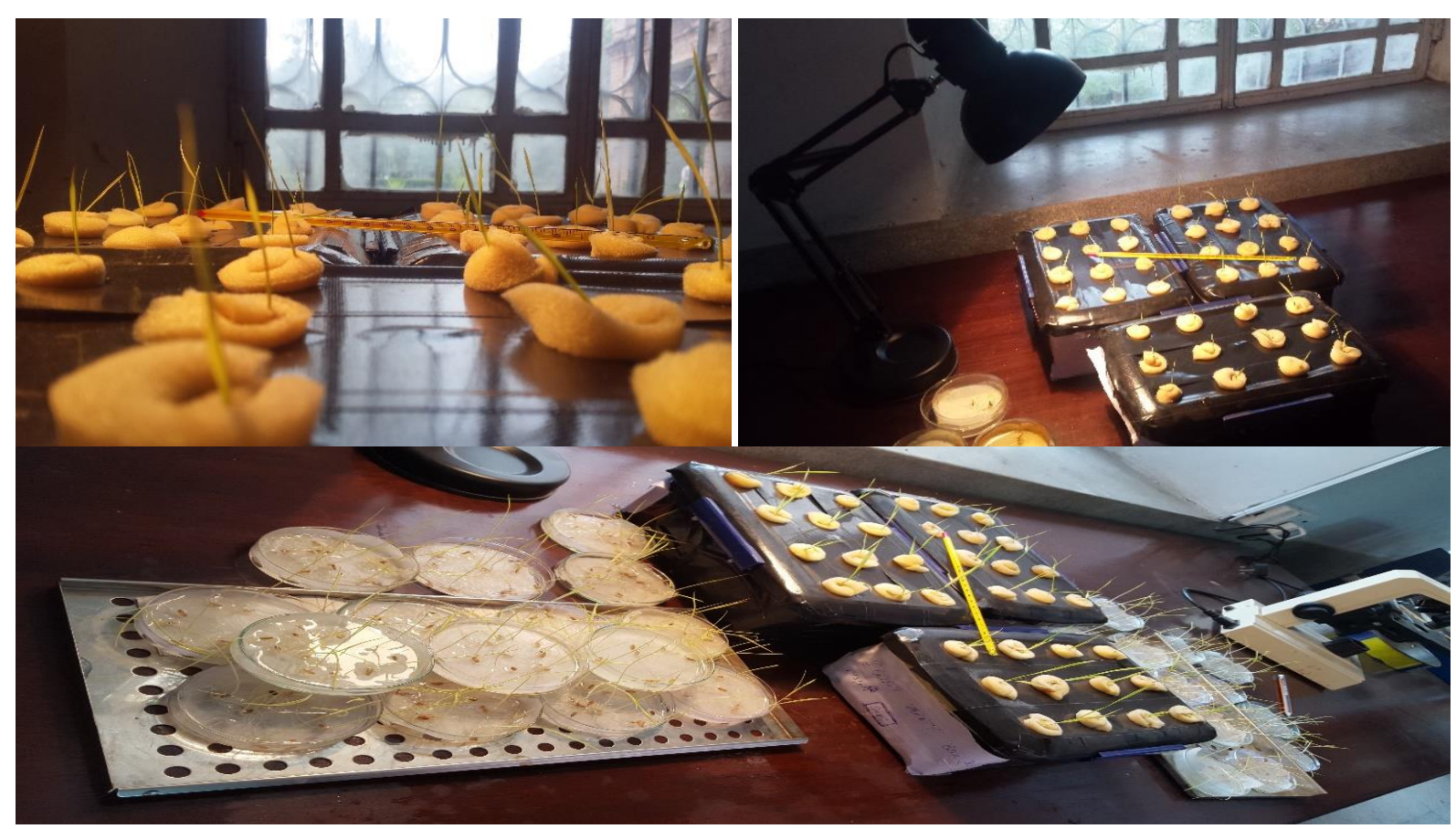

Figure 7. Showing plants germination as well as hydroponic cultivation of rice

\section{Discussion}

These results showed an agreement with the result of some researchers who specified that salinity stress cases decrease in growth i.e. fresh weight of seedling, radicle length of seedling and plumule length of seedling. Plant growth reduces, when the $\mathrm{NaCl}$ concentration is increased [36]. Salinity is most important environment factors that have critical influence on germination and plant establishment i.e. effect imbibition, germination and radicle elongation [37]. The seedling growth i.e. roots length and shoot length is most sensitive to salt stress [38]. Seeds of most of species only germinate in lowest $\mathrm{NaCl}$ concentration [39]. Germination is strongly inhabited at higher salt concentration also the growth of young seedling is reduced, more often at high salt concentration [40]. Due to elevated level of $\mathrm{NaCl}$ salinity causes reduction, delay and sometime hinders germination due to osmotic effect or ionic toxicity [41]. The salt stress effect the plant by providing 
hindrance for absorption of water due to greater osmotic potential out the seedling and lower osmotic potential inside the seedlings so because of which the lower quantity of water is absorbed by the seedling so decreasing the fresh weight of seedling. The $\mathrm{Na}^{+}$also effects the plant growth due to its toxicity but most of all it reacts to plant tissues. It causes osmotion which affect the plant by causing important water in plant tissue to be diverted due to which the tissues dry out loses it length and weight.

It was also found that in control medium the comparison of these two-variety showed that in Punjab Basmati rice variety greater amount of fresh weight of seedlings, plumule length, fresh weight of rice plant, root length, shoot length, and dry weight of plant as compare to that Swat variety which show greater length of radicle and seeds germination.

It can be concluded Punjab Basmati have greater ability to grow in non-saline condition. Whereas the Swat Sella variety is more genetically stronger, have a greater ability to tolerate a saline condition and grow best in saline condition Swat rice plant can adopt to this environment easily as compare to the Punjab Basmati rice variety. The different varieties of wheat show different responses to different condition however the changes also vary among same verities [42].

\section{Conclusion}

It was concluded that salinity affects various growth parameters of the rice plants. The effects are more devastating at high concentrations. In a comparative account the Swat Sella rice variety was found to be better adapted to salinity as compared to Punjab variety.

\section{Author's contributions}

Designing and performing experiments: $S$ Wali \& I Ahmad, designed the experiment: F Tariq, A Ali \& SIU Haq, Carried out research work: S Wali \& F Tariq, Analysed the data: I Ahmad \& S Wali, Contribution material/tools analysed: I Ahmad \& S Wali, Wrote paper: S Wali \& F Tariq.

\section{References}

1. Anonymous (2012) Agricultural research institute Mingora Swat, statistical division, crop reporting service swat, Pakistan.

2. Anonymous (2012) Agricultural statistics of Pakistan. Govt. of Pakistan. Ministry of food, agriculture and livestock (Economic wing Islamabad).

3. Shao HB, Chu LY, Jaleel CA \& Zhao CX (2008). Water-deficit stress-induced anatomical changes in higher plants. Comptes Rendus Biologies 54(3): 215225.

4. Grime JP (1977). Evidence for the existence of three primary strategies in plants and its relevance to ecological and evolutionary theory. The American Naturalist 111(7): 1169-1194.

5. Mittler R (2006). Abiotic stress, the field environment and stress combination. Trends in Plant Science 11(1): 15-19.

6. Araus JL, Slafer GA, Reynolds MP \& Royo C (2002). Plant breeding and drought in C-3 cereals: what should we breed for. Annals of Botany 89(7): 925940.

7. Verslues PE, Agarwal M, Agarwal SK, Zhu J \& Zhu JK (2006). Methods and concepts in quantifying resistance to drought, salt and freezing, abiotic stresses that affect plant water status. The Plant Journal 45(4): 523-539.

8. FAO (2009). High Level Expert Forum How to Feed the World in 2050, Economic and Social Development, Food and Agricultural Organization of the United Nations, Rome, Italy.

9. Musyimi DM, Netondo GW \& Ouma G (2007). Effects of salinity on growth and photosynthesis of avocado seedling. International Journal of Botany 3: 78-84. 
10. Basalah MO (2010) Action of salinity on seed germination and seedling growth of Solanum melongena L. Journal of Agricultural Research Kafer El-Sheikh University 36: 64-73.

11. FAO (2008). FAO Land and Plant Nutrition Management Service. Available online: http://www.fao.org/ag/agl/agll/spush. (Accessed 27/4/2016).

12. Sabouri H \& Biabani A (2009). Toward the mapping of agronomic character on rice genetic map: Quantitative trait loci analysis under saline condition. Biotechnology 144-149.

13. Habib N, Ashraf M \& Shahbaz M (2013). Effect of exogenously applied nitric oxide on some key physiological attributes of rice (Oryza sativa L.) plant under salt stress. Pak J Bot 45(5): 15631569.

14. Galvani A (2007). The challenge of food sufficiency through salt through crops. Rev Env Sci Bioechnology 6: 3-16.

15. Lauchli A \& Grattan SR (2007). Plant growth and development under salinity stress. In: Advances in molecular breeding toward drought and salt tolerant crops, (Eds.): MA Jenks, PM Hasegawa and SM Jain. Springer, Dordrecht, Netherlands.

16. Zeng L, Shannon MC \& Lesch SM (2001). Timing of salinity stress affects rice growth and yield components. Agric Water Manage 48: 191-206.

17. Wahome P, Jesch H \& Grittner I (2001). Mechanisms of salt stress tolerance in two rose rootstocks: Rosa chinensis 'Major' and $R$. rubiginosa. Scientia Horticulturae 87(3): 207-216.

18. Gulzar S \& Khan MA (2001). Seed germination of a halophytic grass Aeluropus lagopoides. Annals of Botany 87: 319-324. doi:10.1006/anbo.2000.1336
19. Munns R (2002). Comparative physiology of salt and water stress. Plant, Cell and Environment 25: 239250.

20. Khan MA \& Gulzar S (2003). Light, salinity and temperature effects on the seed germination of perennial grasses. American Journal of Botany 90(1): 131134.

21. Shereen A, Mumtaz S, Raza S, Khan MA \& Solangi S (2005). Salinity effects on seedling growth and yield components of different inbred rice lines. Pak J Bot 37(1): 131-139.

22. Yamaguchi T \& Blumwald E (2005). Developing salt stress crop plants: challenges and opportunities. Trends in Plant Science 10(12): 615-620.

23. Naheed G, Shahbaz M \& Akram NA (2008). Interactive effect of rooting medium application of phosphorus and $\mathrm{NaCl}$ on plant biomass and mineral nutrients of rice (Oryza sativa L.). Pak J Bot 40(4): 1601-1608.

24. Akhtar MS \& Memon M (2009). Biomass and nutrient uptake by rice and wheat: a three-way interaction of potassium, ammonium and soil type. Pak J Bot 41(6): 2965-2974.

25. Sarwar G, Schmeisky H, Hussain N, Muhammad S, Tahir MA \& Saleem U (2009). Variation in nutrient concentrations of wheat and paddy as affected by different levels of compost and chemical fertilizer in normal soil. Pak J Bot 41(5): 2403-2410.

26. Khan MA, Islam E, Shirazi MU, Mumtaz S, Mujtaba SM, Khan MA, Shereen A, Ashraf MY \& Kaleri GM (2010). Physiological responses of various wheat genotypes to salinity. Pak $J$ Bot 42(5): 3497-3505.

27. Salam A, Ali Z \& Aslam M (2011). Sodium chloride tolerance in rice (Oryza sativa L.) at early seedling growth: 
genotype variability, identification and selection. Pak J Bot 43(6): 2701-2705.

28. Aref F \& Rad HE (2012). Physiological characterization of rice under salinity stress during vegetative and reproductive stages. Indian Journal of Science and Technology 5(4): 2578-2586.

29. Waheed A, Ahmad H \& Abbasi FM (2012). Different treatment of rice seed dormancy breaking, germination of both wild species and cultivated varieties (Oryza sativa L.). J Mater Environ Sci 3 (3): 551-560.

30. Kim Y, Khan AL, Shinwari ZK, Kim D, Waqas M, Kamran M \& Lee I (2012). Silicon treatment of rice (Oryza sativa $\mathrm{L}$. cv 'Gopumbyeo') plants during different growth periods and its effects on growth and grain yield. Pak J Bot 44(3): 891897.

31. Akram H, Ali MA, Sattar A, Rehman HSU \& Bibi A (2013). Impact of water deficit on various physiological and agronomic traits of three basmati rice (Oryza sativa L.) cultivars. The Journal of Animal \& Plant Sciences 23(5): 14151423.

32. Rubel MH, Hassan L, Islam MM, Robin AHK \& Alam MJ (2014). Evaluation of rice genotypes under salt stress at the seedling and reproductive stages using phenotype and molecular markers. Pak J Bot 46(2): 423-432.

33. Zain NAM, Ismail MR, Puteh A, Mahmood M \& Islam MR (2014). Impact of cyclic water stress on growth, physiological responses and yield of rice (Oryza sativa L.) grown in tropical environment. J. Ciência Rural Santa Maria 44(12): 2136-2141.

34. Yoshida S, Forno DA, Cook JH \& Gomes KA (1976). Routine procedure for growing rice plants in culture solution. Laboratory Manual for Physiological Studies of Rice. 3rd ed. Los Banos, Laguna, Philippines: The
International Rice Research Institute 6165.

35. Kaymakanova M (2014). Effect of salinity on germination and seed physiology in bean (Phaseolus Vulgaris L.). Biotechnology \& Biotechnological Equipment 23(1): 326-329. DOI: 10.1080/13102818.2009.10818430.

36. Harradine AR (1982). Effect of salinity on germination and growth of Pennisetum macrourum in southern Tasmania. Journal of applied ecology 19: 273-282.

37. Katembe WJ, Ungar IA \& Mitchell JP (1998). Effect of Salinity on Germination and Seedling Growth of two Atriplex species (Chenopodiaceae). Annals of Botany 82: 167-175.

38. Cordazzo CA (1999). Effects of salinity on seed germination, seedling growth and survival of Spartina ciliate brong. Acta bot bras 13(3): 317-322.

39. Bojovic B, Delic G, Topuzovic M \& Stankovic M (2010). Effects of $\mathrm{NaCl}$ on seed germination in some species from families Brassicaceae and Solanaceae. Solanaceae. Kragujevac J Sci 32: 83-87.

40. Naim AME, Mohammed KE, Ibrahim EA \& Suleiman NN (2012). Impact of Salinity on Seed Germination and Early Seedling Growth of Three Sorghum (Sorghum biolor L. Moench) Cultivars. Science and Technology 2(2): 16-20.

41. Tsegay BA \& Grebreslassle B (2014). The effect of salinity $(\mathrm{NaCl})$ on germination and early seedling growth of Lathyrus sativus and Psium sativum var. abyssinicum. African journal of plant sciences 8(5): 225-231.

42. Raja NI, Rashid H, khan MH, Chaudhry Z, Shah M \& Bano A (2010). Screening of local wheat varieties against bacterial leaf streak caused by different strains of Xanthomonas translucens pv. undulosa (XTU). Pak J Bot 42(3): 1601-1612. 